\title{
Olga Talas (Dodol Garut Berbahan Dasar Talas)
}

\author{
Dalfa Darul Wasilah, Putri Paransucia, Irfan Mariana Akbar dan Irma Fitria Amalia \\ Institut Pendidikan Indonesia \\ Jl. Terusan Pahlawan No.83, Sukagalih, Kec. Tarogong Kidul, Kabupaten Garu \\ dalfadarul@gmail.com
}

\begin{abstract}
Abstrak-Tujuan dari penelitian ini adalah mengembangkan dan memvariasikan rasa dodol namun tetap diminati masyaratkat. Di beberapa tempat oleh-oleh sekitar Garut, belum di temukan variasi dodol dengan bahan dasar makanan pokok tradisional. Pencampuran bahan baku dodol dengan talas menghasilkan dodol talas dengan rasa yang legit dan tekstur yang khas. Dodol talas kemudian dikemas sedemikian rupa sehingga dapat dinikmati dalam satu gigitan (one bite dodol). Selain bentuknya yang unik, dodol talas ini memiliki kandungan gizi yang lebih tinggi. Karena, dalam 100 gram talas mengandung 1,9 gram protein. Proses pembuatan dodol talas diawali dengan mendidihkan santan kental sebanyak $800 \mathrm{ml}$ dan dicampur dengan garam dan mentega. Kemudian ditambahkan $1 \mathrm{~kg}$ gula putih dan $1 \mathrm{~kg}$ gula merah. Selama proses pembuatan, adonan harus terus-menerus diaduk perlahan. Setelah agak mengental, kemudian masukkan $1 \mathrm{~kg}$ tepung ketan yang telah disaring. Tambahkan $1 \mathrm{~kg}$ talas yang sudah direbus dan dihaluskan. Adonan ini terus-menerus diaduk di atas api kecil. Terakhir, tambahkan 2 sachet susu kental manis dan pasta talas secukupnya. Adonan diaduk hingga mengental, kemudian didinginkan selama 24jam. Setelah adonan dingin, adonan kemudian dipotong-potong dan dikemas. Dengan komposisi bahan-bahan tersebut, dodol yang dihasilkan kurang lebih seberat 2,5kg. dodol kemudian dipotong dan dikemas menjadi sebanyak 50 kemasan dengan masing-masing kemasan berisi 10 butir dodol.
\end{abstract}

\section{Kata Kunci- Dodol, Olga Talas}

Abstract-The purpose of this study is to develop and innovate a new variant of dodol by adding taro to the basic materials. Mixing the raw material of dodol with taro produces dodol taro with a distinctive taste and texture. The taro dodol is packaged in such way that it is presented as one bite confection. In addition, the taro dodol is highly nutritious because 100 grams of taro contains 1.9 grams of protein. The making process of taro dodol begins with $800 \mathrm{ml}$ of thick coconut milk, added with salt, butter, $1 \mathrm{~kg}$ of white sugar, and $1 \mathrm{~kg}$ of brown sugar. $1 \mathrm{~kg}$ of smooth glutinous rice flour is added to the mixture as soon as it turns sticky. After that, add mashed boiled taro. The mixture should constantly be stirred over low heat. Lastly, add 2 sachets of sweetened condensed milk and taro paste. The mixture is stirred until it thickens, then cooled for 24 hours. Once cold and thickened, the mixture is then cut into pieces and packaged. This composition can result in more than $2.5 \mathrm{~kg}$ of dodol that can be cut into 500 pieces of dodol ready to be packaged.

Keyword: Garutian Dodol, Dodol Innovation, Taro Dodol

\section{PENDAHULUAN}

Program ini dilatarbelakangi oleh semakin menggeliatnya industri pengolahan dodol di kabupaten garut. Pada tahun 2013, Industri dodol memberikan kontribusi 7,95\% dalam industri pengolahan makanan (BPS Garut, 2014). Akan tetapi berdasarkan survei pasar pada umumnya dodol yang dihasilkan memiliki kemiripan varian rasa seperti rasa susu, wijen, coklat, atau buah- buahan. Dan di beberapa tempat oleh-oleh sekitar, belum di temukan variasi dodol dengan bahan dasar makanan pokok tradisional. Setelah melalui penelitian ternyata di dalam talas memiliki kandungan protein yang sangat tinggi yaitu dalam 100 gram talas mengandung 1,9 gram protein. Kandungan protein dalam talas ini lebih tinggi dibanding dengan singkong dan ubi jalar. Untuk itu kami mengembangkan dan memvariasikan rasa dodol dengan bahan dasar talas.

\section{KAJIAN PUSTAKA}

Menurut Haryadi (2006), dodol merupakan suatu olahan pangan yang dibuat dari campuran tepung beras ketan, gula kelapa, santan kelapa, yang didihkan hingga menjadi kental dan berminyak serta tidak lengket, dan apabila dingin pasta akan menjadi padat, kenyal dan dapat diiris. Jenis dodol sangat beragam tergantung keragaman campuran tambahan dan juga cara pembuatannya.

Bahan baku utama dalam pembuatan dodol adalah tepung beras ketan. Jenis makanan ini berkadar air sekitar 10-40 \% sehingga tidak efektif untuk partumbuhan bakteri dan khamir pathogen, tidak mudah rusak, serta tahan terhadap penyimpanan yang cukup lama tanpa proses pengawetan (Musaddad \& Hartuti, 2003). Untuk pembungkusannya dapat dilakukan dengan menggunakan kertas paraffin atau plastik, agar dodol tidak lekat-lekat dan menempel pada pembungkus.

Talas adalah nama untuk berbagai macam tumbuhan yang lazim ditanam untuk dimanfaatkan umbi atau daunnya. Talas tersebar dalam tiga genus tumbuhan yaitu Colocasia, Xanthosoma, dan Alocasia, dari famili Araceae. Keladi, dasheen, taro, sato imo dan eddo merupakan Colocasia, sedangkan kimpul, 
yautia, tannia dan malanga termasuk Xanthosoma, dan sente serta birah adalah Alocasia. Semua tanaman tersebut dinamakan talas (Nur, 1956).

Talas merupakan bahan makanan pokok bagi masyarakat sebagian besar di dunia ini. Di dalam famili Araceae, talas yang sesungguhnya dikenal dengan nama Colocasia esculenta. Habitat tanaman ini diperkirakan berasal dari daerah tropis antara India dan Indonesia. Talas merupakan bahan makanan pokok bagi masyarakat daerah Pasifik, seperti New Zealand dan Australia (Matthews, 2004).

Talas merupakan tanaman umbi-umbian yang dapat mengeluarkan getah berwarna putih seperti susu. Tanaman ini memiliki daun berbentuk perisai dan warna daun yang sangat bervariasi tergantung varietasnya. Pada setiap permukaan daun dan pelepah tanaman ini dilapisi oleh lapisan lilin untuk melindungi diri. Bentuk umbi talas (colocasia escluenta) adalah lonjong sampai agak membulat dan berdiameter sekitar $10 \mathrm{~cm}$. kulitnya berwarna kemerah - merahan dan dagingnya berwarna putih keruh (Muchtadi dan Sugiyono, 1992).

Talas tidak memerlukan pengairan dalam pertumbuhannya, sehingga dapat tumbuh dengan baik pada daerah kering dan basah. Ketersediaan air yang lebih dominan dan aerasi tanah yang baik akan menunjang pertumbuhan tanaman ini menjadi lebih baik lagi. Talas umumnya dapat tumbuh sepanjang tahun di sekitar daerah dataran rendah sampai dataran tinggi (Onwueme, 1978).

\section{METODE PENELITIAN}

\section{Metode Pengolahan}

Prinsip pembuatan dodol secara tradisional adalah melakukan pencampuran bahan sesuai dengan urutannya dan memasaknya hingga dianggap matang. Masyarakat tradisional meyakini bahwa adonan dodol yang sudah tidak lengket lagi di tangan sebagai indikator telah matangnya adonan dodol tersebut. Sementara itu, untuk pembuatan dodol secara modern, tingkat kematangan dilihat berdasarkan kadar air yang terkandung pada dodol.

Pembuatan dodol talas diawali dengan menyiapkan beberapa alat dan bahan penting seperti wajan, pengaduk, ulekan, tempat mendinginkan dodol, tepung talas atau talas segar, gula pasir, gula merah, garam, santan, mentega, dan tepung ketan.

Langkah-langkah pembuatan dodol talas:
1) Santan dicampurkan dengan garam dan mentega, kemudian dididihkan. Selama proses pemanasan hingga santan mendidih, santan harus terusmenerus diaduk.

2) Tambahkan $1 \mathrm{~kg}$ gula pasir dan $1 \mathrm{~kg}$ gula merah, aduk perlahan agar adonan tidak menggumpal dan tercampur merata.

3) Rebus $1 \mathrm{~kg}$ talas yang telah dicuci bersih dan dipotong, kemudian haluskan. Talas ini bisa diganti dengan menggunakan tepung talas. Pada tahap ini, tepung talas harus disangrai terlebih dahulu.

4) Siapkan $1 \mathrm{~kg}$ tepung ketan, kemudian saring. Tambahkan campuran ini sedikit demi sedikit ke dalam adonan.

5) Selama proses pemasakan, adonan diaduk secara kontinu untuk menghindari gosong pada bagian bawah adonan.

6) Setelah dodol mencapai kematangan yang cukup (tidak terasa lengket di tangan), adonan dodol diangkat dan dituangkan ke dalam wadah plastik untuk selanjutnya didinginkan selama 24jam.

2. Metode Pengemasan

Setelah dodol didiamkan kurang lebih satu hari, dodol dipotong-potong dan dikemas satu persatu seukuran permen (kurang lebih 15 gram). Pada pelaksanaannya, pengemasan dodol talas mengalami beberapa kali perubahan kemasan. Berikut merupakan perkembangannya:

1) Potongan dodol dikemas menggunakan plastik bening berukuran $(6 \times 6) \mathrm{cm}$, kemudian dimasukkan ke dalam kemasan mika plastik bening ukuran $(7 \times 7 \times 3) \mathrm{cm}$. tiap kemasan berisi 6 buah dodol talas.

2) Hampir sama dengan kemasan sebelumnya, namun plastik bening diganti dengan kertas lilin berwarna putih dan merah. Penggunaan kertas lilin menyebabkan dodol lama kelamaan menjadi lengket sehingga sukar dilepas dari kemasan kertas. Kemasan mika sudah ditempel dengan label merk Olga Talas

3) Potongan dodol kembali menggunakan plastik bening, namun kemasan luar sudah tidak menggunakan mika plastik. Kemasan luar menggunakan plastik bening yang cukup memuat 10 buah dodol, dasarnya menggunakan potongan dus tipis, kemudian dikemas dan diikat dengan menggunakan pita kawat berwarna ungu. Kemasan kemudian ditempel label merk Olga Talas. 
4) Untuk lebih meningkatkan daya jual, kemasan plastik diganti dengan menggunakan aluminium foil foodgrade warna silver ukuran $(8 \times 8) \mathrm{cm}$. Kemasan luar menggunakan kraft paper standing pouch ukuran $(10 \mathrm{x} 15) \mathrm{cm}$, tiap kemasan berisi 10 buah dodol. Kemasan standing pouch kemudian ditempel label merk Olga Talas.

3. Metode Pemasaran

Langkah pertama sebelum diluncurkan ke pasaran adalah melakukan uji organoleptik. Uji organoleptik atau uji indra atau uji sensori merupakan cara pengujian dengan menggunakan indra manusia sebagai alat utama untuk pengukuran daya penerimaan terhadap produk (Wikipedia).

Uji organoleptik dilakukan kepada rekan-rekan di kampus, para dosen, maupun staf Fakultas. Hasilnya adalah produk dodol yang berbahan dasar talas yang dihaluskan lebih disukai dibandingkan dengan produk dodol dengan bahan dasar tepung talas.

Pemasaran yang telah dilakukan dari awal produksi sampai akhir produksi yaitu

1) Menjual produk dengan harga yang terjangkau oleh masyarakat.

2) Menyebarkan brosur yang berisikan tentang keunikan, keunggulan, serta manfaat produk.

3) Membuat event untuk memancing keramaian, untuk mengenalkan produk

4) Menjual produk secara online melalui sosial media dan market place

5) Menawarkan produk via online dan juga secara langsung kepada rekan kerja ataupun teman kuliah.

6) Membangun jaringan partner bisnis. Menyediakan waktu untuk promo diskon khusus

7) Memperkenalkan produk ke instansi terdekat

\section{HASIL DAN PEMBAHASAN}

Hasil pembuatan produk pertama digunakan untuk uji organoleptik, hal ini bertujuan untuk evaluasi dan perbaikan produk. Dari hasil uji organoleptik diketahui bahwa dodol talas dengan bahan dasar talas yang dihaluskan lebih disukai di banding dodol talas dengan bahan baku tepung talas. Dari uji organoleptik juga kami mengetahui bahwa ukuran dodol yang dibuat sudah sesuai untuk dimakan satu kali gigitan (one bite dodol).

Dari tabel tersebut kita dapat mengetahui bahwa produksi olga talas mengalami peningkatan keuntungan setiap bulannya.
Tabel 4.1 Tabel hasil produksi

\begin{tabular}{|c|c|c|c|c|c|}
\hline $\begin{array}{l}\text { Pro } \\
\text { duks } \\
\text { i ke- }\end{array}$ & $\begin{array}{l}\text { Dana } \\
\text { yang } \\
\text { terpakai } \\
(\mathbf{R p})\end{array}$ & $\begin{array}{l}\text { Dodol } \\
\text { yang } \\
\text { dihasil } \\
\text { kan } \\
\text { (pes) }\end{array}$ & $\begin{array}{l}\text { Harga } \\
\text { pokok } \\
\text { per } \\
\text { pcs } \\
(\mathbf{R p})\end{array}$ & $\begin{array}{l}\text { Harga } \\
\text { jual } \\
\text { per } \\
\text { kemasa } \\
\text { n } \\
\text { (Rp) }\end{array}$ & $\begin{array}{l}\text { Keuntun } \\
\text { gan }\end{array}$ \\
\hline 1. & 202.000,- & 500 & $404,-$ & $3.500,-$ & $47.712,-$ \\
\hline 2. & 198.500,- & 700 & $283,-$ & $2.500,-$ & $51.900,-$ \\
\hline \multirow[t]{2}{*}{3.} & $128.698,-$ & 670 & $192,-$ & $2.000,-$ & $62.320,-$ \\
\hline & & & & Jumlah & 161.932, \\
\hline
\end{tabular}

Selain laporan kemajuan, artikel ilmiah dan produk, luaran lainnya yang telah di capai yaitu PIRT agar produk dapat diperjualbelikan di pasaran, maka produk tersebut harus memiiki izin. Berhubung olga talas merupakan industri rumahan, maka izin yang diperlukan adalah PIRT (Pangan Industri Rumah Tangga). Izin ini dikeluarkan oleh Dinas Kesehatan kabupaten Garut, namun untuk proses registrasi dan kelengkapan persyaratan dilakukan di Dinas Perindustrian dan Perdagangan. Adapun untuk mendapatkan sertifikat PIRT tersebut, kami harus mengikuti PKP (Penyuluhan Keamanan Pangan). Penyuluhan keamanan pangan untuk tahun 2019 akan dilaksanakan pada bulan September sehingga saat ini kami belum memenuhi syarat untuk mendapatkan sertifikat PIRT. Jika sertifikat PIRT sudah didapat, maka kami akan medapatkan nomor PIRT untuk produk olga talas. Sertifikat PIRT ini merupakan salah satu syarat untuk mengajukan sertifikat halal ke MUI. Dengan demikian, produk olga talas ini pun belum mendapat sertifikasi halal MUI mengingat belum didapatnya sertifikat PIRT. Saat ini, perizinan yang telah didapat adalah NIB (Nomor Induk Berusaha) yang dikeluarkan oleh DPMPT (Dinas Penanaman Modal dan Perizinan Terpadu) kabupaten Garut. Dari berbagai kegiatan yang telah direncanakan, mulai dari produksi, perizinan, dan pemasaran, berikut merupakan rincian kegiatan yang sudah terlaksana maupun belum terlaksana: 
Tabel 2 Target Pemasaran

\begin{tabular}{|c|c|c|c|}
\hline No & Target & Terlaksana & $\begin{array}{c}\text { Belum } \\
\text { terlaksana }\end{array}$ \\
\hline 1 & $\begin{array}{l}\text { Menjual produk } \\
\text { dengan harga yang } \\
\text { terjangkau oleh } \\
\text { masyarakat }\end{array}$ & $\sqrt{ }$ & \\
\hline 2 & $\begin{array}{l}\text { Menyebarkan brosur } \\
\text { yang berisikan } \\
\text { tentang keunikan, } \\
\text { keunggulan, serta } \\
\text { manfaat produk. }\end{array}$ & & $\checkmark$ \\
\hline 3 & $\begin{array}{l}\text { Menjaga kualitas } \\
\text { rasa }\end{array}$ & $\checkmark$ & \\
\hline 4 & $\begin{array}{l}\text { Membuat dan } \\
\text { menyebarkan peta } \\
\text { lokasi penjualan }\end{array}$ & $\checkmark$ & \\
\hline 5 & $\begin{array}{l}\text { Menjual produk } \\
\text { secara online melalui } \\
\text { social media dan } \\
\text { market place }\end{array}$ & $\sqrt{ }$ & \\
\hline 6 & $\begin{array}{l}\text { Menawarkan produk } \\
\text { via online dan juga } \\
\text { secara langsung } \\
\text { kepada rekan kerja } \\
\text { ataupun teman } \\
\text { kuliah }\end{array}$ & $\checkmark$ & \\
\hline 7 & $\begin{array}{l}\text { Membuat kemasan } \\
\text { lebih unik supaya } \\
\text { dapat lebih menarik } \\
\text { konsumen }\end{array}$ & $\sqrt{ }$ & \\
\hline 8 & $\begin{array}{l}\text { Membangun } \\
\text { jaringan partner } \\
\text { bisnis }\end{array}$ & $\sqrt{ }$ & \\
\hline 9 & $\begin{array}{l}\text { Menyediakan waktu } \\
\text { untuk promo diskon } \\
\text { khusus }\end{array}$ & $\checkmark$ & \\
\hline 10 & $\begin{array}{l}\text { Memperkenalkan } \\
\text { produk ke instansi } \\
\text { terdekat }\end{array}$ & & $\checkmark$ \\
\hline & Total & $80 \%$ & $20 \%$ \\
\hline
\end{tabular}

\section{KESIMPULAN DAN SARAN}

Produk olga talas ini selain berkontribusi bagi kabupaten Garut juga bermanfaat dalam segi social, yaitu membuka lapangan pekerjaan sehingga meningkatkan taraf ekonomi masyarakat sekitar, sekaligus mengajak masyarakat untuk mencintai produk tradisional.

Selain itu, olga talas juga bermanfaat dari segi kesehatannya. Pertama dari tepung beras ketannya mampu memenuhi kebutuhan zat besi 4 kali lebih banyak dari sepotong kue, rendahnya kadar natrium baik dikonsumsi oleh penderita hipertensi, serta rendah kalori baik dikonsumsi oleh orang yang sedang diet, manfaat lainnya yaitu melancarkan pencernaan, menambah energi, dan memperlancar aliran darah. Manfaat yang dihadirkan dari produk ini, selain manfaat dari dodolnya sendiri terkandung manfaat dari talasnya yaitu mengandung 1,9 gram protein dalam 100 gram talas, Sementara itu, singkong hanya memiliki kandungan protein sebesar 1,2 gram dan ubi jalar sebanyak 1,8 gram protein, mengandung energi sebanyak 98 kkal dapat mengatasi masalah pencernaan, darah tinggi, membantu penglihatan, kesehatan kulit dan rambut, system kekebalan tubuh dan aliran darah. produk usaha ini juga sudah memiliki surat izin usaha yang resmi dari pemerintah setempat, supaya dapat terjamin kualitas produknya.

\section{REFERENSI}

[1] Keegan, W. (2003). Manajemen Pemasaran Global, Jakarta : PT. Gramedia Pustaka Utama

[2] Tanton,W. J. (2002). Prinsip Pemasaran, Edisi 7 , Alih Bahasa : Y. Lamarto dan Sadu Sundaya. Jakarta : Erlangga.

[3] Winarno, F.G (1992). Kimia Pangan dan Gizi . Jakarta : PT. Gramedia Pustaka Utama.

[4] Repository. "Target dan luaran" https://repository.unej.ac.id/bitstream/handle/123 456789/57911/7.Target\%20dan\%20Luaran.pdf?s equence $=7$ (diakses 12 juni 2019)

[5] Ubpkarawang. "analisis produk pemasaran produk umkm dodol garut" http://journal.ubpkarawang.ac.id/index.php/Manaj emen/article/view/164 (diakses 12 juni 2019)

[6] Repository. "studi deskriptif tentang pengembangan usaha dodol garut" http://repository.upi.edu/27061/4/S_PEK_120386 8_Chapter\%201.pdf (diakses 13 juni 2019)

[7] Roro diyah. "20 manfaat pada tepung garut" https://manfaat.co.id/manfaat-tepung-garut (diakses 17 juni 2019)

[8] Wikipedia. "Uji Organoleptik" https://id.wikipedia.org/wiki/Uji_organoleptik (diakses 17 Juni 2019)

[9] Repository. "PRODUKTIVITAS TALAS (Colocasia esculenta L. Shott) DI BAWAH TIGA JENIS TEGAKAN DENGAN SISTEM AGROFORESTRI DI LAHAN HUTAN RAKYAT" https://repository.ipb.ac.id/jspui/bitstream/123456 789/61934/2/BAB\%20II\%20Tinjauan\%20Pustak a.pdf (diakses 5 juli 2019) 